\title{
共有と再利用を考慮した設計情報の統合表現
}

\section{A Method of Integrated Description of Design Information for Reusability}

妻屋 彰
Akira Tsumaya
永江 政郎
Masao Nagae
若松 栄史
Hidefumi Wakamatsu
自瀬 敬一
Keiichi Shirase
荒井 栄司
Eiji Arai

\author{
大阪大学工学研究科 \\ Graduate School of Engineering, Osaka University \\ tsumaya@crcast.osaka-u.ac.jp, http://www6.mapse.eng.osaka-u.ac.jp/index.shtml \\ 大阪大学工学部 \\ School of Engineering, Osaka University \\ 大阪大学工学研究科 \\ Graduate School of Engineering, Osaka University \\ wakamatsu@mapse.eng.osaka-u.ac.jp, http://www6.mapse.eng.osaka-u.ac.jp/index.shtml \\ (同上) \\ shirase@mapse.eng.osaka-u.ac.jp, http://www6.mapse.eng.osaka-u.ac.jp/index.shtml \\ (同上) \\ arai@mapse.eng.osaka-u.ac.jp, http://www6.mapse.eng.osaka-u.ac.jp/index.shtml
}

keywords: CAD, concurrent design, designers' intention, design process, knowledge engineering

\section{Summary}

Much of product design is executed concurrently these days. For such concurrent design, the method which can share and ueuse varioud kind of design information among designers is needed. However, complete understanding of the design information among designers have been a difficult issue.

In this paper, design process model with use of designers' intention is proposed. A method to combine the design process information and the design object information is also proposed. We introduce how to describe designers' intention by providing some databases. Keyword Database consists of ontological data related to design object/activities. Designers select suitable keyword(s) from Keyword Database and explain the reason/ideas for their design activities by the description with use of keyword(s). We also developed the integration design information management system architecture by using a method of integrated description with designers' intension. This system realizes connections between the information related to design process and that related to design object through designers' intention. Designers can communicate with each other to understand how others make decision in design through that. Designers also can re-use both design process information data and design object information data through detabase management sub-system.

\section{1. は じめ に}

製品の高付加価値化や多樣化に伴い, 現在の設計は異 なった知識背景を持つ複数領域の専門家達による協調作 業として行われることか増えている.このような協調し ながら行う設計では, 樣々な設計情報を複数の人間で等 しく共有することが必要とされる．また，近年製品ライ フサイクルがますます短くなってきているため, 得られ た情報を効果的に再利用することによって設計時間を短 縮化することか望まれている.このような背景から，協 調設計時の情報の容易で正確な共有や，蓄積された情報 の効果的な再利用を考慮した設計情報表現の枠組みが必 要とされている.これに対して樣々な研究が行われ，光 の成果として異なる $\mathrm{CAD}$ システム間でのデータの互換 やシステム全体の統合などか実現されている [吉川 89, 吉
岡 98] が，現在に至るまで設計情報の伝達と炎の理解は 困難な課題となっている.これは，従来の CAD システム が主として設計結果としての設計物兴のものの情報を扱 い, 途中に行われる設計者の思考弚のものについてほと んど扱っていなかったことに起因すると考えられる．つ まり，他の設計者は設計物谷のものの情報を得ることが できても，弚れがどのような考えの基に出てきたのかと いう点を知ることができず，これが迅速かつ正確な設計 情報の理解を妨げている .

従来の CAD システムで設計者の思考弚のものの表現 があまり扱われていない理由として，設計者の思考過程 は光のほとんどか設計者自身の頭の中で行われるために 具体的な表現として現れることが少ないことが挙げられ る．さらに，思考過程を確認するために，設計後にどの ような思考がなされたのかという点を尋ねても設計者自 
身も完全には説明できない場合がしばしばある．実験的 手法を用いて, 設計活動のプロトコルを収集し分析した 研究 [Cross 96] は設計者の思考過程を追跡するのには有 効であるが，解析に膨大な手間と時間がかかるため実際 の設計現場に適用することは困難であると思われる .こ のように実際の設計の場面で設計者の思考を情報として 計算機で扱うことは難しいが, 設計者の思考の中でも決 定するときの設計者の意図は設計の決定に直接関係する という点で特に重要な役割を持つと考えられ，これを設 計情報として表現することは設計情報の理解のために必 要であると考えられる．

設計者の意図を取り込むことを試みた研究はこれまで にも，複数部品間の要求機能と光れを実現する概念形状 要素を結合するための知識表現の研究 [荒井 98] や，機 能，構造，形状を機構の応答関係を用いて設計意図を表 現することによって結びつける研究 [知念 98] など幾つ かの研究が行われているが, 設計意图兴のものが言葉と して明示されているものはほとんどない，しかし，選定 理由 , 失敗理由 , 仮定の設定などの設計者行為と直接結 びつく意図は，設計者の思考の途中経過及び結果として， 設計者が比較的明示的に表現することができる．このた め, 設計行為から弚の理由を表現することによって設計 意図を知ることは設計を行った設計者，協調している他 の設計者双方にとって比較的容易であると考えられる．

一方, 設計者の思考過程を知るための手段としては, 設 計者が行う活動を記録し表現するという方法も考えられ る.設計プロセス記録は設計者が思考した結果行った設 計活動の記録であるため，思考過程を見いだす手がかり となりうる．また，設計プロセスを表現することにより， 協調設計においてこれまでどのようなプロセスで設計が 行われて来たかという点を他の設計者に明示することが できる．従って，設計対象物に関する情報を表現する際 に，設計プロセス及び設計意図と対応させることにより， 設計情報の共有がより容易になると考える．また，設計 情報に決定理由等の設計意図を付加することにより，他 の設計物設計時での情報の再利用性も向上すると考えら れる.

そこで本論文では, 設計中の決定理由や失敗理由など の表現を設計者の意図と捉え,設計者の活動を記録した 設計プロセスと設計対象物に関する情報を設計意図によっ て結びつけることによって，設計者間の情報の共有や再 利用を支援する枠組みを提案する．

\section{2. 設計情報の表現手法}

本章では, 設計意図を中心に設計情報を表現し，設計 プロセスに関する情報と設計物の機能に関する情報を結 びつける方法について説明する．まず，設計対象情報と 設計プロセス情報を統合的に管理する意義と光のときの 設計意図情報の重要性について述べ, 弚れを受けて統合
管理を行うための設計意図と設計プロセスの表現方法を 提案する.

\section{$2 \cdot 1$ 設計情報・プロセス統合管理の目的}

設計作業では, 設計プロセスの進行に伴って機能分解 や，機構，形状の詳細化などの設計行為がなされて設計 対象情報が変化する．ここで, 設計プロセスを管理する ことにより設計に関わるどの属性を思考しているのかと いう点について明確化するだけでなく, 設計プロセス中 のどのプロセスをどのように発展させて各々の属性を導 出したかという理由に設計意図を用いた表現を導入する ことで, 設計意図を用いた設計対象物に関する情報と設

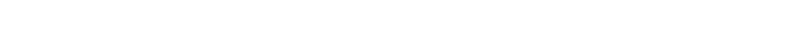
となる .ここで書かれる設計意図情報は設計の決定理由 などの記述であり，すなわち要求される機能を実現する 方式の選択理由をも表現しているため，機能実現方式の 決定にも役立てることができる．乥こで，ここでは設計 対象情報と設計プロセス情報の統合表現のために仲立ち として設計意図記述を用いる。しかし, 設計意図は通常 設計者の頭の中だけに留まり明示的に表現されることは 少ないため, ここでは設計意図の表現方法として設計者 に文章で自由に記述してもらう方法を提案する .

以上をまとめると，ここで考える機能情報と設計プロ セスの統合管理システムに要求される機能は以下のよう になる．

（1）各設計プロセスにおける意図の明確化 設計プロセスと各々のプロセスでの設計者の意図 を結びつけて表現する仕組みが必要である．これに より各プロセスについて設計者がなぜ弚のような設 計活動・行為を行ったのかということを他の設計者 に明示することが可能となり，行われている設計に 関する他の設計者の理解を助けることができる . ま た，設計プロセスと炎の意図の関係を収集し，光れ らを分析して分類整理することによって, 設計の実 現方式を見いだせる可能性がある .これらの情報を 設計実現方式として分類できれば，収集した設計プ ロセスと設計意図の関係は設計実現方式を設計者に 示唆するための事例ベースとして利用することがで きる .

(2) 設計プロセス進展の設計対象表現への反映 設計プロセスは設計者の活動を記録したものとし て表現することができるが，これらの活動は設計者 がなんらかの意図を持って行うものである.また ,こ のように設計者がなんらかの意図を持って設計活動 を行った結果, 設計対象表現に対して付加・削除・変 更・参照などの操作がなされる.すなわち, 設計プ ロセスと設計対象表現は同じ設計意図に基づく設計 者の活動と設計対象への影響を各々表現したもので あるといえる．乥こで，設計意图を仲介にして設計 プロセスと設計対象表現を結合させる機能が必要で 
ある

（3）任意のプロセスの参照と復帰

ここで要求される機能は任意のプロセスについて， 設計者がどのようなことを意図していたか光の内容 や，光のときの設計対象の状態などを参照可能にす ることである．これにより，設計情報の理解という 点では設計者間の意図の誤解による誤認を減ずるこ とができる．また，設計作業ではしばしは試行錯誤 の結果やり直しや修正が発生するが, 各々のプロセ スが行われていた時点での設計情報の状態を管理す ることにより，部分的，あるいは設計全体を任意の プロセスを行った時点の状態へ即座に戻すことも可 能となる。

(4) 設計履歴と乥の再利用

設計行為は乥の成功・失敗に関係なく実際の設計 経験として大切な知識であり，これを弚の行為を行っ た意图をも含めて蓄積することは有用である . 光れ にもかかわらず, これまでそのほとんどは設計者の 頭の中だけに留まり，乥の知識を多くの設計者が利 用できるようにはなっていない，乥こで，設計対象情 報と設計プロセスを結びつけて管理することにより 得られる設計に関する情報を, 設計行為の履歴と光 れに対応する設計対象情報で記述された設計事例と して蓄積し，再利用を可能にすることが要求される．

これらの要求を考慮して, 設計意図と設計プロセスの 表現手法の開発を行う．最終的には樣々な種類の設計対 象情報と設計プロセス情報の統合管理を目標としている が，本研究では第一段階として設計対象情報の代表例の 一つである機能情報に注目して設計意図，設計プロセス との統合表現を試みる .

\section{$2 \cdot 2$ キーワードを用いた設計意図表現}

先にも述べたように設計者が行う設計活動の背後には 常に設計意図が存在する。しかし，設計意図は普通設計 者か顗の中で考えているものであり，意識して意図を主 張するような場合を除くと，他の設計者に対して設計意 図が明示されることは少ない，乥こで，設計者に対して 明示的に設計意図を表現してもらうため, 設計者の自由 記述によって設計意図を表現してもらうことを提案した。

しかし，自由記述による設計意图表現は情報の背後に ある設計意図を的確に表現し，他の設計者へ伝達するこ とには有効であると考えられるが，記述谷のものを計算 機になじむデータとして体系化し整理することは困難で あり，光のため計算機を利用したデータの再利用もあま り見込めない，乥こで，設計意図情報を管理するために設 計に関する樣々な用語を設計キーワードとして用い，設 計意図記述にこのキーワードを用いることにする．これ によって，次のような利点が得られると考えられる．

・設計キーワードを設計意図記述の入力時にキーワー ドテンプレートとして用いることにより，設計意図
記述の入力行為を支援するとともに用いる語彙のば らつきをおさえることができる .

・設計意図記述には設計キーワードが用いられている ため，これを用いて検索することにより，設計者が 意図していることに関する事例の再利用や情報の利 用が容易となる。

・設計キーワードを通して，ある情報に関連する情報 を検索することができる．

・機能に関する設計キーワードの階層を参照すること により機能分解を支援することができる．

・設計変更を行う時に，光れに伴う影響のあるデータ を設計用語キーワードを通して検索し，設計者に提 示することができる .

ここで設計キーワードには，これまでの設計方法論研 究やオントロジー工学などを用いて体系化された機能や 機構, 部品などの設計知識を基に，階層化したテンプレー トとして用意する . 本研究では , ドイツ流の機能分解で 考慮される機能の分類 [Pahl 88] や，機能概念オントロ ジーの研究の成果 [佐野 00] をベースに機能を中心として 機能 - 副機能の関係で設計用語の整理を行った .この際， 設計者の思考過程では抽象度からの視点と構造からの視 点を一緒に用いていると考えられるため，本研究では機 能 - 副機能の階層表現に抽象度に関する抽象 - 具体の階 層と機能構造に関する全体 - 部分の階層の二種類の階層 を導入している．弚の分類の一部を図 1 に示す．例えば 「変える」という用語の下位リンクには「状態を変える」 と「方向を変える」の 2 つがあるが，これらはいずれも 「変える」という機能とは抽象 - 具体の関係て階層構造と なっており，「変える」という機能に特性を付加すること によってより具体的な機能を表す言葉になっている .こ のような木構造で体系化された設計用語を通して，設計 意図記述の体系的な整理が可能となる．また，予め用意 したテンプレートだけでなく，実際の設計現場で用いら れている用語を設計キーワードに随時追加したり関連づ けしたりできるようにすることで, 若干汎用性は失うが 各々の分野でより使いやすいように設計キーワードを調 整することができるようにしている .

\section{$2 \cdot 3$ 設計プロセス表現}

次に設計プロセスの整理について述べる. 設計者間の 設計プロセスを含む設計情報の共有と蓄積した設計プロ セス情報の再利用を考慮すると，設計プロセスの表現に は以下の 3 つの内容が必要であると考えられる .

（1）設計情報の分岥, 取り消し, 後戻り等の表現 設計プロセスでは試行錯誤の結果しばしば設計情 報の分岐, 取り消し，後戻りなどが起こる．これら の行為が行われる場合には以前の段階の設計プロセ スの時点に設計情報の一部または全部を戻さなくて はならない . 従って各々の設計プロセスと光の時点 の設計対象情報をセットで管理する必要がある 。 


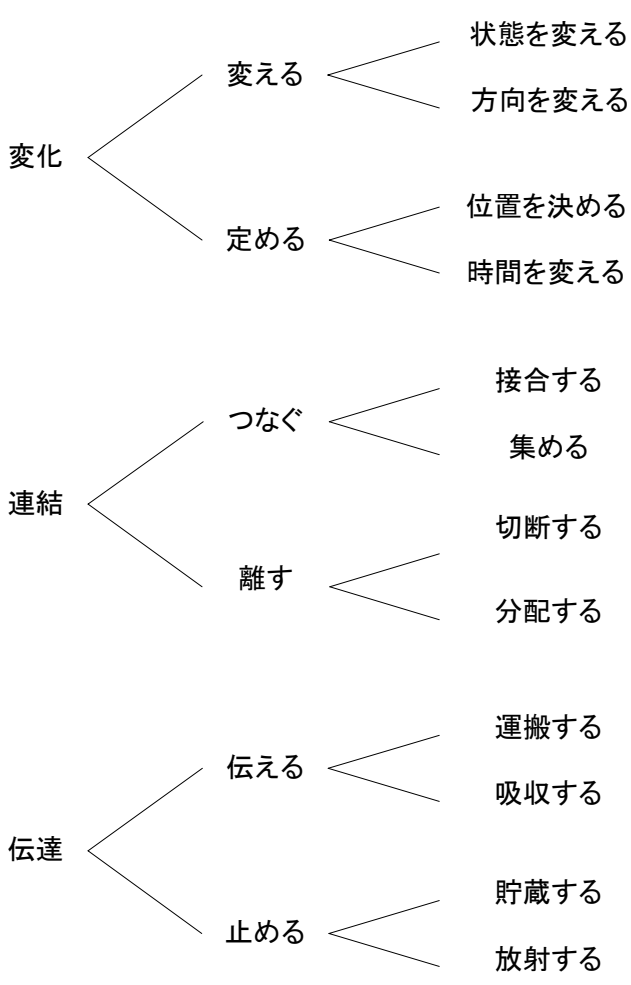

図 1 設計用語分類の例

（2）設計意図の表現

各々の設計プロセスは設計者の意図に基づいて行 われる．乥こで，設計プロセスと光れに対応する設 計意図を結びつける必要がある。

（3）設計プロセス理解の容易性，設計プロセスの再利 用性

細かな設計プロセスの全てを产のまま提示すると 情報量が莫大なため，他の設計者にとって把握する ことは大変な作業になる．また，情報の再利用性の 面からもプロセスの粒度があまり細かすぎると情報 として扱いにくい，乥こで，設計プロセスに含まれ る要素・行為のうち密接に関連している複数要素・ 行為をまとめて構造化し，理解しやすく表現するこ とが必要である.

このうち, 最初の 2 つにつては先に述べた設計意図 表現を用いることによって実現できるが，より設計情報 の理解を容易に行うことを考えると，3つ目の要求が重 要となる. 従って当該設計における逐次的な設計プロセ スだけでなく, 意味を持つひとまとまりの設計プロセス を構造化してまとめたプロセス表現も必要だと言える . 乥こで，本研究では主に当該設計での使用を目的とする 逐次的な基本プロセスと，再利用を主たる目的とする構 造化プロセスの 2 種類で設計プロセスを表現することを 提案する . 図 2 に基本プロセスの構造化の概念図を示す.

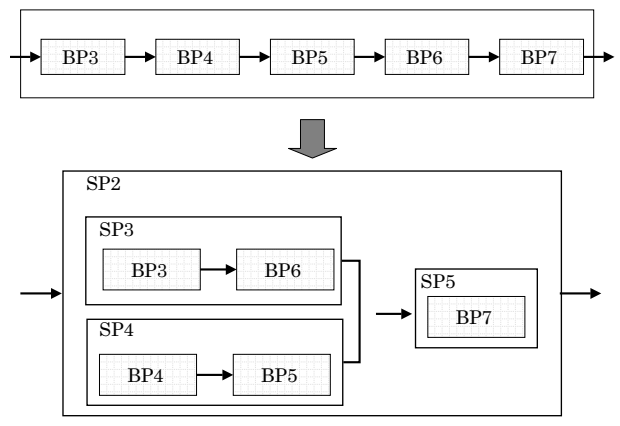

BP: 基本プロセス, SP: 構造化プロセス

図 2 設計プロセスの構造化

ここで, 逐次的プロセスである基本プロセスは知識デー タの検索や弚れを利用した機能の分解, 決定理由の記述 などの設計者の行為を逐次データとして記録したもので ある。

基本プロセスの構造化は, 設計者の基本的な設計プロ セスが知識を収集し検討して決定するという行為の繰り 返しであると考えられるため, 本研究では知識データを 検索するところから機能を分解して产の意図を記述する 行為までを機械的にまとめて一つの構造化プロセスとし て取り扱う. しかし，一連の設計行為に付随する更なる プロセスの存在や関連プロセスの発生など基本パターン に当てはまらないケースも多く存在することが予想され るため, 構造化プロセスのチェックと修正は基本的には設 計者自身によって行うことにする．逐次的なプロセスの 構造化を設計者が行うことは設計者にとって負担となる が，一方で設計者の意図を明確にするだけでなく，行っ た設計行為をまとめることで設計内容自体も見つめ直す ことになるため，暧昧であったり，修正や改良が必要で あることに気づくということが起こり得ると考えられる． また，設計プロセスも構造化プロセスのパターンとして 分類することができると考えられるため, 構造化プロセ スを整理しデータベース化することにより，構造化を自 動で行うことのできる設計プロセスのパターンを増やす ことができ，設計者にかかる負担も減っていくと考えら れる。

このようにして作られた構造化プロセスは設計者の意 図や光の結果なされた設計も内包するため，これを整理 してデータベース化することによって, 設計方式のオント ロジデータとして有効に再利用できることが期待できる．

\section{3. 設計情報の統合管理システム}

本章では，前節で述べた設計プロセスと設計意図の表 現手法を用いて設計情報の統合管理を行うシステムを構

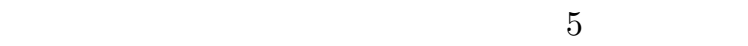

・設計キーワードを設計意図記述の入カテンプレート 


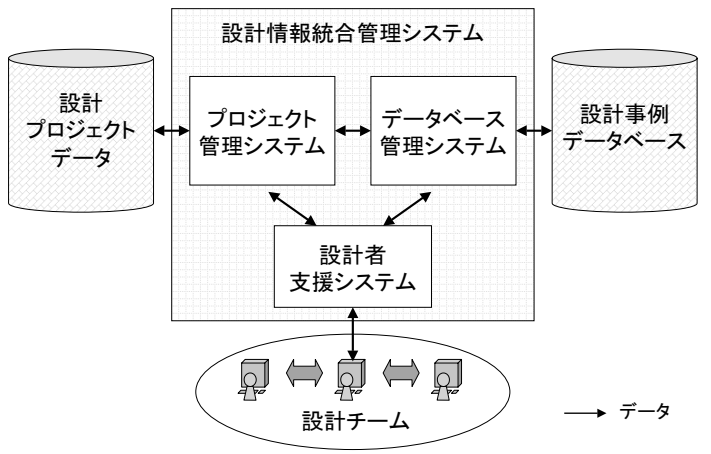

図 3 設計情報統合管理システムの構成

として用いることにより, 設計者の設計意図入力を 支援する．

・設計キーワードを用いて設計意図情報を整理し，再 利用性を高める .

・設計の過程で得られた機能情報，設計意図情報，プ ロセス情報を整理し，他の設計者か理解しやすいよ うに表現する．

・データベース化した各種データを設計キーワードを 通じて相互に参照できるようにして設計者の創造活 動を支援する。

・再利用性のある一連の設計プロセスを構造化プロセ スとしてまとめ，データベース化して再利用性を高 める .

以上の目的を考慮し，図 3 に示すような 3 つのサブシ ステムとデータベースからなるシステムを構築する．以 下で各システム及びデータベースについて説明する .

\section{$3 \cdot 1$ 設計者支援システム}

設計者支援システムは, 設計者と計算機との間のイン タフェース部分にあたる、設計者の作業を支援し，兴の 内容に応じて他の 2 つのサブシステムに指示を出し, 連 携を取ってデータを取り扱う役割を持つ。

このシステムは設計対象の詳細化に関する設計行為を 支援する設計行為支援システムと，共有および再利用を 考慮して行われるデータ操作を支援するデータ操作支援 システムからなる. 設計行為支援システム部は設計対象 操作支援機能, 設計意図記述支援機能, データ参照支援 機能, データ管理機能を持ち, 設計行為として行う機能 分解, 変更, 設計意図の記述, 参照などの支援を取り扱 う.データ操作支援システム部はプロセス構造化支援機 能, データベース管理システム操作支援機能を持ち, 設 計プロセスの構造化, 設計用語の定義 , 各種データのデー タベース化などを支援する .

\section{$3 \cdot 2$ プロジェクト管理システム}

プロジェクト管理システムは, 現在進行中の各種設計 情報データを管理する .このシステムは, 設計プロセス， 設計意図，機能情報を各々管理する 3 つのサブシステム と設計情報間の整合性を管理するためのサブシステムか ら構成され，光れらは关れ光れ以下の 4 機能のいくつか を持つ.

\section{・基本プロセス自動記録機能}

設計者と設計者支援システムとのやりとりを通じ， 逐次的に発生する基本プロセスを設計者支援システ ムから受け取り，記録する。

・データ管理機能

設計の進行によって設計者支援システムから送ら れてくるデータを指示に従って管理する．

\section{・データ配信機能}

作業中の各設計者に対して作業中，または作業結 果のデータを配信する。

・作業者管理機能

設計者の各データに対する権限を管理する．また， データ配信のため作業中の設計者を管理する .

\section{$3 \cdot 3$ データベース管理システム}

データベース管理システムは過去の設計事例や，設計 用語などが格納されている設計事例データベースを管理 する.このシステムは設計者支援システムの指示にした がって, 各種データベースのデータ操作を行う.設計者 支援システムから指示される参照や検索などの作業命令 に応じてデータを絞り込む，必要性の度合いに応じデー 夕を並べ替えるなどの操作を行う機能であるデータ操作 機能, データベースの更新や削除, プロジェクトデータ からデータベースへの移行など, データベース光のもの に対する操作を行うデータベース操作機能 , 各種データ ベースへの各設計者の権限を管理するアクセス管理機能 を持つ.

\section{$3 \cdot 4$ データの構成}

最後に本システムで扱う設計情報データの構成を述べ る.設計プロジェクトデータと設計事例データベース内 のデータは共に図 4 で表される各種のデータから構成さ れている.設計プロセス，機能情報など，全ての設計情 報データ及び炎の間の関係は設計意図データで説明され ており, 設計意図データからのリンクを通して接続され， 相互の関係が説明されている.設計意図データは光の意 図記述のキーワードとして設計用語を用いており，設計 用語からのリンクによって検索したり整理することなど が可能である、また，設計用語はキーワード名，キーワー ドの内容, 階層が上位, 下位のキーワードへのリンクの 情報を持つ. 本研究で試作したシステムでは類義語や分 野による用語の使われ方の違い等に対しては対応してお らず課題として残っているが , キーワードの内容を確認 


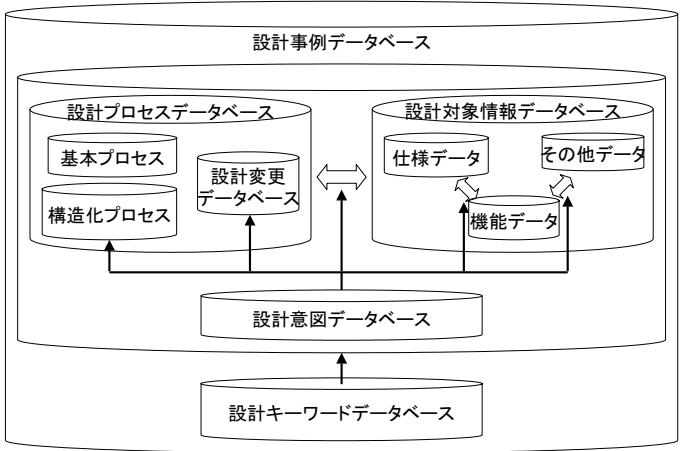

図 4 各種データの構成

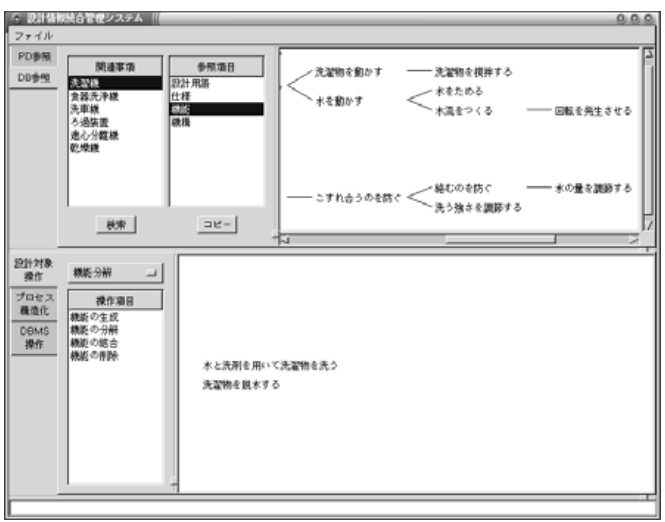

図 5 実行画面
することによって設計用語の用法を設計者が知ることは できるようになっている．次に，設計プロセスデータの うち基本プロセスデータは, 弚のプロセスが行われた時 間 , 前後のプロセスへのリンク, 設計者が行った操作と システムが返す結果，対応する設計意図データ，機能情 報データへのリンクの情報を持つ．これらのデータは全 て設計者がシステムに対して操作を行ったときにシステ ムによって自動的に生成・記録される．構造化プロセス は, 対応する全ての基本プロセス, 設計意図データ, 機能 情報データへのリンク情報を持っている.試作システム ではプロセスの構造化パターンは, 同一の機能情報, 設 計意図を持ち，知識データの検索，機能情報の分解，設 計意図の記述の順に出現する基本プロセスを構造化する というーパターンのみの実装であり，かなりの部分は設 計者自身の手により構造化や自動生成プロセスの修正が 行われることになるが，実際に事例を積み重ねていくこ とにより構造化パターンのバリエーションか増え, 設計 者の負担は減ると考えられる

ここで, 設計プロジェクトデータと設計事例データベー スは同樣の構造をしているのにもかかわらず, 別々に格 納されているが, 同樣の構造をしているのは, 現在行わ れているか，過去の事例かによらず設計に関する情報は 同質であるためであり，格納場所を別々にしているのは， 情報の内容か頻繁に書き変わる可能性のある現在進行中 の設計情報データは，既になんらかの評価が行われてい る設計事例データとは当該設計においては担っている役 割が違うためである。

\section{4. システムの実装と実行例}

\section{$4 \cdot 1$ 実 装}

本研究で提案した設計情報の統合管理システムの試作 を行った . パイロットシステムは Linux の統合デスクトッ プ環境の1つである GNOME1.2 上で，C++を用いて作 成し, gcc-2.95.2 を用いてコンパイルして構築した .GUI の構築には GTK+1.2.0を用いた . 作成した試作システ
ムにはデータとして約 300 語の設計用語を実装し，また 事例データとして後に述べる実行例て例題とした洗濯機 の設計事例を 5 例用意した .

作成したシステムの実行画面のスナップショットを图 5 に示す . システムのメインウィンドウは大きく上下に 2 つのエリアを持っているが上のエリアが主にデータ参照 を行う参照画面 , 下のエリアか現在行っている設計に関 する情報を取り扱う作業画面となっている . 参照画面で はキーワードを用いて検索される関連事項や参照したい データの種類を選択することにより，設計事例データや プロジェクトデータを参照することができる．また，コ ピーコマンドにより必要に応じて設計事例データをテン プレートとして作業画面に転記することができる．作業 画面では左端のタブを選択することにより，設計対象操 作, プロセス構造化, データベース操作という 3 種類の 質の異なる作業を切り替えて行うようになっている．

作業は主としてメインウィンドウで行うが, 必要に応 じてシステムは検索キーワード入カウィンドウや設計意 図表示ウインドウ, 設計意図記述ウインドウなどを生成・ 表示することで, 設計者に対し，情報を提示したり作業 を促したりする .

\section{$4 \cdot 2$ 実 行 例}

システムの実行例として，洗濯機の改良設計を例題と して説明する．まず最初に「水と洗剂を用いて洗濯物を 洗う」「洗濯物を脱水する」という 2 つ要求仕樣が与 えたと仮定する．弚のときシステムは「洗う」「水分を 取り除く」というキーワードから関連事項として「洗濯 機」や「食器洗浄機」などの事項を表示する.ここでは 洗濯機の設計を考えているため，関連事項中から洗濯機 を選択し，さらに参照項目として機能を選んで検索する と，設計事例データベースから検索された従来行われて いる洗濯機の設計事例の機能分解木が図 5 に示すように 関連事項表示ウィンドウに表示される .

ここで, 技術進展により小型で高トルクのモータが開 


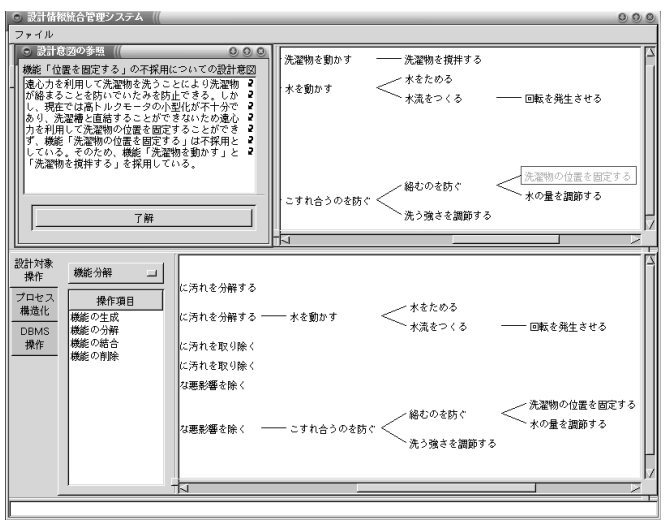

図 6 設計修正の実行例

発されたとして，検索キーワードに「モータ」「小型」， 「高トルク」の 3 つを記述して検索を行うと，「選択物の 位置を固定する」という機能か漒調表示された状態で参 照画面に表示される .これは，「設計物の位置を固定する」 という機能は，「遠心力を利用して選択物を洗う方法は， 高卜ルクモータの小型化が充分でなく，洗濯機全体のサ イズの拘束により洗濯槽と直結できない」という理由の 失敗事例として事例データベースに蓄えられていて，小 型高卜ルクモータの開発によって，この不採用要因が消 えたためである「洗濯物の位置を固定する」という機能 は,「洗濯物を痛めない」という要求仕樣から展開された 機能として付け加わったが，ここで過去失敗時に記述さ れた設計意図を参照すると，「遠心力を利用して洗濯物を 固定することにより，洗濯物が絡まるのを防いでいたみ を防止できる」という記述がある . 失敗理由だった高卜 ルクモータの小型化が実現し，「洗濯物を痛めない」とい う要求を満たすことから遠心力を利用して「洗濯物の位 置を固定する」機能を採用することにする．乥こで，こ の機能を選択して機能の分解操作を行うことで, 图 6 に 示すように作業画面に「洗濯物の位置を固定する」とい う機能が付け加わり，逆に「洗濯物の位置を固定する」と いう機能と相反する機能である「洗濯物を動かす」「洗 濯物を擋拌する」といった機能が削除される.

このように，本システムを利用することにより，設計 事例をキーワードを基にして検索し，光の時の意図を確 認しながら利用できることから，過去の事例を有効に活 用できると思われる . また , プロジェクトデータについて も設計者が設計意図を記述することにより，他の設計者 へ各々の設計対象情報がどのような意図で変更されたの か, 設計プロセスがどのような意図で行われたのか , な どが明確に伝達できると考えられる .

\section{5. ま と め}

本研究では, 設計情報の理解や過去の設計事例の有効 利用には設計者の意図記述を付加することが不可欠であ
るという考慮から，設計中に用いられる語彙やオントロ ジー工学などにより体系化された知識を設計用語として 定義してキーワードに用い, 設計用語を用いて記述され る設計意図を通して設計情報を統合的に扱うシステムを 提案した .設計用語の利用により，設計者の文字入力の 支援が可能である, 設計対象の関連要素を検索・提示す ることが容易になるという利点が得られた．また，設計 意図記述を用いて設計情報や設計情報間の関係を表現す ることにより，設計者間での理解や，過去の設計情報の 理解が容易となった .これらのことから，提案したモデ ルは設計情報の共有や再利用に対して，有効な手段とな り得ることを示した 。

\section{謝辞}

本研究の一部は日本学術振興会未来開拓学術研究推進 事業「人工知能による協調的シンセシスの方法論」プロ ジェクト (JSPS-RFTF 97P00701) の研究費により実施 された ・ここに記して謝意を表する .

\section{$\diamond$ 参 考 文 献 $\diamond$}

[荒井 98] 荒井, 赤坂, 若松, 白瀬: CAD における設計意图モデ ルと修正設計への適用，日本機械学会論文集 (C 編)，Vol. 64, No. 627, pp. 4492-4497 (1998).

[知念 98] 知念, 若松, 白瀬, 荒井 : 協調設計のための機能情報と 幾何情報の統合表現, 日本機械学会第 9 回設計工学・システム 部門講演会講演論文集, pp. 339-341 (1998).

[Cross 96] Cross, N., Christiaans, H., and Dorst, K. eds. Analysing Design Activities, John Wiley \& Sons (1996).

[Pahl 88] Pahl, G. and Beitz, W.: Engineering Design: Systematic Approach, Springer-Verlag (1988).

[佐野 00] 佐野, 来村, 溝口 : 機能依存関係”メ夕機能”に基づく 機能構造の導出に関する考察, 第 18 回設計シンポジウム講演論 文集, pp. 21-28 (2000).

[吉川 89] 吉川, 畐山 : インテリジェント CAD ——理念とパラ ダイム— (上巻) , 朝倉書店 (1989).

[吉岡 98] 吉岡, 冨山 : 設計支援のための統合モデリング環境の 研究 一プラガブル・メタモデル機構の提案 —, 人工知能学 会誌, Vol. 13, No. 2, pp. 312-319 (1998).

〔担当委員 : 瀧 寛和〕

2001 年 8 月 1 日 受理

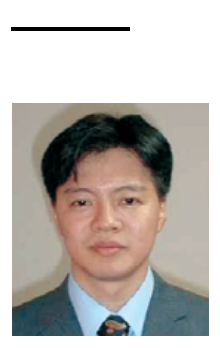

者 紹 介

\section{妻屋彰(正会員)}

1998 年 3 月東京大学大学院工学系研究科システム量子工 学専攻博士課程修了, 博士 (工学). 同年 4 月東京大学人 工物工学研究センターリサーチ・アソシエイト. 2000 年 4 月大阪大学先端科学技術共同研究センター助手. 2001 年 4 月大阪大学大学院工学研究科助手, 現在に至る. 設計 方法論, 統合設計システムに関する研究に従事。日本機械 学会, 精密工学会, 日本原子力学会各会員. 


\section{永江 政郎}

2001 年 3 月大阪大学工学部応用理工学科卒業. 同年 4 月 株式会社メイテック入社, 現在に至る

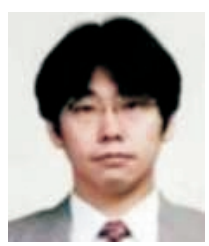

\section{若松 栄史}

1994 年 3 月大阪大学大学院工学研究科電子制御機械工学 専攻修士課程修了. 1995 年 4 月大阪大学大学院工学研究 科助手, 現在に至る。博士 (工学)。変形しやすい物体の マニピュレーション，CADに関する研究に従事，日本機 械学会, 精密工学会, 日本ロボット学会各会員.

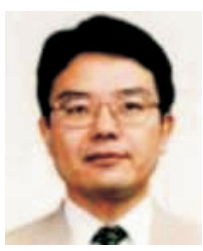

白瀬 敬一

1984 年 3 月神戶大学大学院工学研究科生産機械工学専攻 修士課程修了.同年 4 月金沢大学工学部助手. 1995 年 7 月金沢大学工学部助教授.1996 年 10 月大阪大学大学院 工学研究科助教授、現在に至る. 工学博士. 知能化・自律 化工作機械，CAD/CAMに関する研究に従事。日本機 械学会, 精密工学会, ASME, ASPE 各会員。

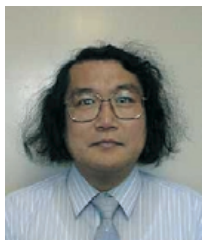

荒井 栄司

1980 年 3 月東京大学大学院工学系研究科精密機械工学專 攻博士課程修了. 工学博士. 同年 4 月神戶大学工学部助手。 1984 年 4 月静岡大学工学部助教授 . 1992 年 4 月東京都 立大学工学部助教授. 1995 年 4 月大阪大学大学院工学研 究科教授, 現在に至る。機械設計の次世代 CAD/CAM に関する研究に従事。日本機械学会, 精密工学会, 設計工 学会各会員. 